\title{
Effect of Diet Containing Different Amount of Wheat Dried Distillers' Grain as a Substitute for Alfalfa Hay on Holstein Lactating Cow Responses
}

\author{
S. Gohari ${ }^{1}$, M. DaneshMesgaran ${ }^{1 *}$, A. R. Vakili ${ }^{1}$ and M. Mojtahedi ${ }^{1}$ \\ ${ }^{1}$ Dept. of Animal Science, Excellence Centre for Animal Science, Faculty of Agriculture, \\ Ferdowsi University of Mashhad, P O Box 91775-1163, Mashhad, Iran.
}

Authors' Contributions

$S G$ wrote the protocol, performed the experiment and wrote the manuscript; MD supervised the experiment and revised both protocol and manuscript; $A R V$ and MM performed the analyses of the study.

Research Article

Received $28^{\text {th }}$ December 2011

Accepted $12^{\text {th }}$ June 2012

Online Ready $17^{\text {th }}$ June, 2012

\section{ABSTRACT}

Wheat dried distillers' grain (WDDG) as a co-product has a high content of neutral detergent fiber (NDF) and crude protein (CP), due to the selective removal of starch during the production process. Therefore, it has been proposed to use this by product as a good source of non-forage fiber in ruminant rations. The objective of this study was to evaluate the effect of diets containing different amount of Wheat dried distillers' grain as a partial substitute for alfalfa hay on lactation performance, blood metabolites and chewing activity of lactating Holstein dairy cows. Nine primiparous Holstein lactating dairy cows $(76 \pm 18$ days in milk) were assigned randomly to a replicated $3 \times 3$ Latin square design with $21 \mathrm{~d}$ periods. Basal diet (BD) was provided using $31.2 \%$ alfalfa hay, $15.6 \%$ corn silage, $12.5 \%$ barley grain, $12.5 \%$ corn grain, $8.6 \%$ cottonseed, $7.1 \%$ wheat bran, $10.5 \%$ soybean meal and $2 \%$ premix on dry matter basis. Alfalfa hay and soybean meal was partially substituted with WDDG as 5\% (BD+WDDG5) and 8.7\% (BD+WDDG8.7). Experimental diets were calculated to achieve same amount of $\mathrm{CP}$ and metabolizable energy. Throughout the experiment, cows were housed in tie-stalls barn and fed ad libitum a total mixed ration twice daily at 008 and $1800 \mathrm{~h}$. Dry matter intake (DMI) and milk yield was recorded daily. 
Milk samples were collected weekly at each milking, then, analyzed for protein, lactose and fat. Blood samples were drawn from the jugular vein into heparinized evacuated tubes on the last day of each experimental period at $4 \mathrm{~h}$ post-feeding, then, plasma was provided. Plasma samples were analyzed to determine glucose and urea-N concentrations. Chewing activity (i.e. eating, ruminating, idle)for cows were monitored over a $24 \mathrm{~h}$ by manually observing individual cows every $5 \mathrm{~min}$. Inclusion of WDDG in the experimental diets did not affect DMI, milk yield, milk composition, blood glucose. Except for total chewing activity ( $\mathrm{min} / \mathrm{kg} \mathrm{NDF}$ ) that was decreased significantly with inclusion of WDDG, all other evaluating indices were not affected by treatments. However, diet containing WDDG at $5 \%$ caused a significant decrease $(\mathrm{P}<0.05)$ in blood plasma urea- $\mathrm{N}$ compared with that of the cows fed basal diet $(B D=21.6$ and $B D+W D D G 5=19.9 \mathrm{mg} / \mathrm{dl})$. Therefore, it was concluded that WDDG might include in the lactating cow diets, up to $8.7 \%$, without any negatively impacting on milk yield, milk composition and blood metabolites evaluated.

Keywords: Wheat dried distillers' grain; lactating cow; milk; chewing activity.

\section{INTRODUCTION}

Distiller's dried grains as non-forage sources of fiber are a co-product of bio-ethanol production from cereal grains. Due to the selective removal of starch during the production process, it has a high content of NDF and crude protein (CP), allowed to use this by product as a good source of protein and energy in the diet of ruminants. This is mainly due to their high digestible fiber content and ruminal escape protein levels (Mustafa et al., 2000).

Forages usually are the major source of fiber in dairy rations. Non-forage sources of fiber have a low lignin content and large proportion of potentially digestible fiber (Mojtahedi and DaneshMesgaran, 2011) that supply energy needed for lactation without the ruminal acid load caused by rapidly fermented starchy concentrates (Rezaii et al., 2009, 2010, 2011). Non-forage sources of fiber also may serve as partial replacements for forage fiber in those situations where forage availability is limited. Compared with most forage, non-forage sources of fiber typically have a smaller particle size and relatively high specific gravity which promote particle passage from the rumen (Creswell, 1958; Kaske and Engelhardt, 1990). Various experiments were conducted to evaluate animal health and performance responses of lactating Holsteindairy cows fed diets formulated by partial replacement of forage effective neutral detergent fiber (eNDF) with an equal estimated amount of eNDF from a mixture of non-forage sources of fiber (Pereira et al., 1999). In addition, the ability to prevent depression of milk fat concentration, relative to alfalfa haylage, was evaluated (Swain and Armentano, 1994). It has been reported that ruminal NDF digestibility was equal for diets of similar total NDF content formulated by partial replacement of forage with non-forage sources of fiber (Cunningham et al., 1993). However, the (NDF) from most Non-forage sources of fiber does not stimulate chewing activity as effectively as forage NDF (Pereira and Armentano, 2000). Decreased chewing activity when non-forage sources of fiber replace forage can decrease the flow of salivary buffer to the rumen, decreasing rumen $\mathrm{pH}$ and NDF degradation (Grant and Mertens, 1992). Chewing activity and rumen pH of lactating cows decreased when soy-hulls replaced $42 \%$ of dietary forage in a $59 \%$ forage diet and total NDF was increased from 28 to $34 \%$ of diet DM (Weidner and Grant, 1994). 
There are varying approaches for the inclusion of distillers' grains into the diets of lactating dairy cattle. Most often, distillers' grains have been included in the diets as an energy and protein supplement by replacing a portion of the dietary concentrate especially with soybean meal (Anderson et al., 2006, Batajoo and Shaver, 1998). They contain a valuable source of supplemental protein with high rumen undegradability, that $60 \%$ of crude protein as compared to $37 \%$ in soybean meal (Batajoo and Shaver, 1998; NRC, 2001). They also contain other nutrients recovered from fermented grains. These include low soluble carbohydrates, relatively high fiber, high fat and factors that stimulate cellulose digestion in the rumen (Hatch, 1993). Because of the high fiber content in distillers' grains, it may be possible to use them as a partial forage replacement (Clark and Armentano, 1993; Penner et al., 2009).

The objective of this study was to evaluate the effect of Wheat dried distillers' grain substitution for alfalfa hay on the lactation performance, blood metabolites and chewing activity of lactating Holstein dairy cows.

\section{MATERIALS AND METHODS}

\subsection{Animals, Diets and Experimental Design}

Nine primiparous lactating Holstein dairy cows with average live weight of $559 \mathrm{~kg}$ and $76 \pm$ 18 days in milk were assigned randomly to a replicated $3 \times 3$ Latin square design with $21 \mathrm{~d}$ periods. Each $21 \mathrm{~d}$ period consisted of $14 \mathrm{~d}$ adaptation period and $7 \mathrm{~d}$ sampling period. Throughout the experiment, cows were housed in a tie-stalls barn and were individually fed a total mixed ration (TMR) at 0800 and $1700 \mathrm{~h}$ and milked in a herringbone parlour thrice daily at 0500,1300 and $2130 \mathrm{~h}$. theWDDG used in this study was without soluble and Chemical composition of WDDG is in Table 1.

Table 1. Chemical composition (\% of DM) of wheat dried distillers grains (WDDG) and alfalfa hay

\begin{tabular}{lll}
\hline Item & WDDG & Alfalfa hay \\
\hline CP & 28.93 & 18.1 \\
ADF & 17.60 & 40.1 \\
NDF & 47.14 & 43.2 \\
NPN (\% of CP) & 10.50 & - \\
Ash & 6.00 & 8.00 \\
EE & 4.93 & 1.50 \\
\hline
\end{tabular}

Basal diet (BD) was provided containing $530 \mathrm{~g} / \mathrm{kg}$ of concentrate and $470 \mathrm{~g} / \mathrm{kg}$ of forage (Table 2). Alfalfa hay was partially substituted with WDDG as Treatment 1 (BD+WDDG5) contained 5\% WDDG, 28.1\% alfalfa hay and 8.7\% SBM, and Treatment 2 (BD+WDDG8.7) contained $8.7 \%$ WDDG, 25.2\% alfalfa hay and 7.1\% SBM. Experimental diets were calculated to achieve same amount of CP and ME.

\subsection{Sample Analysis}

Samples of individual feedstuffs and TMR were dried at $60^{\circ} \mathrm{C}$ in an oven for $48 \mathrm{~h}$, ground through a $1 \mathrm{~mm}$ screen in a Wiley Mill (Arthur Hill Thomas Co., Philadelphia, PA). Samples of individual feedstuffs and TMR were analyzed for DM, ASH (determined after $5 \mathrm{~h}$ of oxidation 
at $500^{\circ} \mathrm{C}$ ), ether extract, Kjeldahl N (AOAC, 1990), NDF and ADF (Van Soest et al., 1991). Sodium sulfate was used in the NDF analysis. NDF assayed without a heat stable amylase and expressed including residual ash. Non-protein $\mathrm{N}$ was estimated by incubating $2 \mathrm{~g} \mathrm{DM}$ equivalent of DWDGsamples in $3 \mathrm{M}$ sodium tungstate solution and determining $\mathrm{N}$ in residual sediments (NPN was thencalculated as the total $\mathrm{N}$ minus residual sediments $\mathrm{N}$ ).

Dry matter intake (DMI) and milk yield was recorded daily throughout the $7 \mathrm{~d}$ collection period. Milk samples were collected from 3 consecutive milkings during 3 and $5 \mathrm{~d}$ of each sampling period and then predicted for protein, lactose and fat (Foss System 4000, Foss Electric, Hillerod, Denmark). Blood samples were drawn from the jugular vein into heparinized evacuated tubes on the last day of each experimental period at $4 \mathrm{~h}$ post-feeding. Samples were centrifuged at $1500 \times$ gfor $10 \mathrm{~min}$ and the plasma was frozen at $-20^{\circ} \mathrm{C}$ prior to determine the urea- $\mathrm{N}$ and glucose concentration. The concentration of urea- $\mathrm{N}$ and glucose determined with an automatic blood chemical analyzer (SELECTRA trade mark) with the use of a commercially available kit (man kit).

Table 2. Ingredients (\% of DM) and chemical composition of basal diet (BD) and diets containing of wheat dried distillers grain as a partial substitute for alfalfa hay at the rate of $5 \%(B D+W D D G 5)$ and $8.7 \%$ (BD+WDDG8.7)

\begin{tabular}{|c|c|c|c|}
\hline \multirow[t]{2}{*}{ Items } & \multirow[b]{2}{*}{ BD } & \multicolumn{2}{|c|}{ Experimental diets } \\
\hline & & BD+WDDG5 & BD+WDDG8.7 \\
\hline \multicolumn{4}{|l|}{ Ingredients } \\
\hline Alfalfa hay & 31.2 & 28.1 & 25.2 \\
\hline corn silage & 15.6 & 15.6 & 15.6 \\
\hline barley grain & 12.5 & 12.5 & 12.5 \\
\hline corn grain & 12.5 & 12.5 & 12.5 \\
\hline soybean meal & 10.5 & 8.7 & 7.1 \\
\hline Wheat dried distillers grain & - & 5.0 & 8.7 \\
\hline cottonseed & 8.6 & 8.6 & 8.6 \\
\hline wheat bran & 7.1 & 7.1 & 7.1 \\
\hline Premix & 2.0 & 1.9 & 2.7 \\
\hline \multicolumn{4}{|c|}{ Chemical composition(\% ofDM) } \\
\hline $\mathrm{CP}$ & 18.19 & 17.98 & 17.95 \\
\hline ADF & 26.03 & 23.55 & 22.05 \\
\hline NDF & 32.51 & 33.4 & 33.85 \\
\hline Forage NDF ( $\%$ of NDF) & 65.82 & 60.47 & 54.94 \\
\hline $\mathrm{ASH}$ & 8.50 & 8.70 & 7.75 \\
\hline EE & 3.75 & 4.18 & 4.45 \\
\hline $\mathrm{P}$ & 0.34 & 0.32 & 0.31 \\
\hline $\mathrm{S}$ & 0.24 & 0.21 & 0.21 \\
\hline $\mathrm{Na}$ & 0.35 & 0.34 & 0.34 \\
\hline $\mathrm{Cl}$ & 0.37 & 0.35 & 0.35 \\
\hline $\mathrm{I}(\mathrm{mg} / \mathrm{kg})$ & 2.40 & 2.40 & 2.40 \\
\hline
\end{tabular}




\subsection{Chewing Activity}

Chewing activity (i.e. eating, ruminating, idle) were monitored over $24 \mathrm{~h}$ duration on $\mathrm{d} 4 \mathrm{~d}$ of each sampling period by manually observing individual cows every $5 \mathrm{~min}$. the recorded activity was assumed to extend for the entire 5 min interval. Chewing activity was also monitored during milking and during the transition to and from the milking parlor.

\subsection{Statistical Analysis}

Data were analyzed using the MIXED procedure of SAS 9.1 (2004). The model included the fixed effects of square, period and treatment, and the random effect of cow nested within square. The model of experiment was:

$$
Y_{i j k}=\mu+C_{i}+P_{j}+T_{k}+e_{i j k}
$$

Where $\mu$ is the overall mean, $C_{i}$ is the random effect of cow (i $=1$ to 9$), P_{j}$ is the fixed effect of period ( $j=1$ to 3 ), $T_{k}$ is the fixed effect of treatment ( $k=1$ to 3 ), and $e_{i j k}$ is the residual, assumed to be normally distributed. Differences between least squares means were considered significant at $p<0.05$, using PDIFF in the LSMEANS statement.

\section{RESULTS AND DISCUSSION}

\subsection{Feed Intake, Lactation Performance and Blood Metabolites}

Data of dry matter intake, lactation performance and blood metabolites of the animals used in the present experiment are shown in Table 3. Dry matter intake was not affected $(P>0.05)$ by decreasing forage NDF and with increasing WDDG in the diet (Table 2). Allen (2000), showed that DMI by lactating cows was maintained in most studies when non-forage fiber sources replaced forage. It was also reported that DMI did not decrease when dried brewers grains was included in cow diets (Younker et al., 1998). The potential filling effects of WDDG and lack of DMI depression in the present study may be explained by ruminal digestion process. It has been proposed that wheat dried distillers grains appeared to have a faster outflow rate than forage (corn silage plus alfalfa silage) but a slower NDF digestion rate than that of alfalfa silage (Younker et al., 1998). The replacement of forage NDF with NDF from WDDG might have decreased the digestion rate but increased the passage rate of NDF, apparently counteracting effects on rumen fill and, therefore, DMI in this study. Replacement of forage with wet corn gluten feed (Allen and Grant, 2000) or a new wet milling corn product (Broddugari et al., 2001) had no consistent effect on overall ruminal NDF digestion rate, whereas passage rate increased in both studies. Therefore, all WDDG diets in the current study supporting the potential for WDDG to serve as a partial forage replacement in diets meeting NRC (2001) guidelines for DMI.

Milk yield and milk composition including fat and protein were not affected by WDDG diets. In addition, the lack of response in milk fat and protein yields would support the hypothesis that WDDG have a similar effectiveness compared with the control diet. Apparently, the decrease in ADF concentration (Table 2) and providing similar amount of NDF with increasing WDDG was not large enough to affect lactation performance, while energy intake was almost constant among the animals used (Firkins et al., 2002). Because milk fat is dependent on fiber digestion and production of fermentation acids in the rumen, it is thought 
to be the most complete measure of effective NDF, often used as an indicator of rumen health and may indicate inadequate peNDF for the WDDG diet (Zebeli et al., 2006; Armentano and Pereira, 1997), therefore similarity of milk fat between present treatments imply that NDF of WDDG can effectively prevent milk fat depression. Kalscheur (2003), showed similar milk fat with inclusion of distillers' dried grains like this study too.

At level of $5 \%$ WDDG, there was a decrease in blood urea-N concentration (Table 3). There is a positive relationship between blood urea- $\mathrm{N}$ concentration and ruminal NH3-N concentration (Dann and Varga, 1999). Therefore, feeding diets with higher ruminally available NDF as WDDG to lactating cows may be more desirable. Thus, feeding diets with $5 \%$ WDDG might have benefits on animal health as observed in reduced blood Urea-N concentration (Dann and Varga, 1999).

Table 3. Effect of inclusion of wheat dried distillers' grain as a partial substitute for alfalfa hay of basal diet (BD) at the rate of 5\% (BD+WDDG5) and $8.7 \%$ (BD+WDDG8.7) on the lactation performance and blood metabolites of Holstein lactating dairy cows

\begin{tabular}{|c|c|c|c|c|c|}
\hline \multirow[t]{2}{*}{ Items } & \multicolumn{3}{|c|}{ Experimental diets } & \multirow[t]{2}{*}{ SEM } & \multirow[t]{2}{*}{ P-value } \\
\hline & BD & BD+WDDG5 & BD+WDDG8.7 & & \\
\hline Dry matter intake $(\mathrm{kg} / \mathrm{d})$ & 22.3 & 22.58 & 22.66 & 0.23 & 0.62 \\
\hline Milk yield $(\mathrm{kg} / \mathrm{d})$ & 35.38 & 35.53 & 36.11 & 0.49 & 0.56 \\
\hline Milk fat (\%) & 3.40 & 3.19 & 3.40 & 0.10 & 0.28 \\
\hline Milk fat $(\mathrm{kg} / \mathrm{d})$ & 1.20 & 1.13 & 1.22 & 0.04 & 0.37 \\
\hline Milk protein (\%) & 2.85 & 2.90 & 2.80 & 0.03 & 0.26 \\
\hline Milk protein $(\mathrm{kg} / \mathrm{d})$ & 1.00 & 1.03 & 1.10 & 0.02 & 0.66 \\
\hline Milk lactose (\%) & 4.89 & 4.81 & 4.86 & 0.06 & 0.50 \\
\hline Blood glucose (mg/dl) & 76.52 & 77.94 & 75.72 & 1.65 & 0.09 \\
\hline Blood urea (mg/dl) & $21.63^{a}$ & $19.91^{b}$ & $21.13^{\mathrm{a}}$ & 0.34 & 0.001 \\
\hline
\end{tabular}

\subsection{Chewing Activity}

Table 4 summarizes chewing activity as influenced by dietary treatment.Except for total chewing activity (min/kg NDF) that was decreased significantly with inclusion of WDDG, all other evaluating indices were not affected by treatments (Table 4). Non-forage sources of fiber do not stimulate rumination activity as effectively as dietary forage because of their small particle size (Mertens, 1997). Therefore, it is important to consider the effective NDF content of these fiber sources. Effective NDF has been estimated with three approaches including:

1) Change in milk fat concentration (Armentano and Pereira, 1997)

2) Change in rumination activity (Allen, 1997)

3) Sieving and particle size analysis (Mertens, 1997).

Rumination activity has been used as an estimate of the physical effectiveness of fiber sources at stimulating salivary secretion and ruminal buffering (Allen, 1997). In the present study, we did not measure the peNDF content, but similar chewing activity and milk fat content between treatments indicate that peNDF value is same among treatments. This speculation is supported by Zebeli et al. (2006), which conducted a meta-analysis using 33 
experiments with 131 treatments and determined that chewing time was positively correlated with dietary physically effective NDF (peNDF) content.

Table 4. Eating, ruminating and chewing activity of lactating Holstein dairy cows fed diets containing wheat dried distillers grain as a partial substitute for alfalfa hay in basal diet (BD) at the rate of 5\% (BD+WDDG5) and 8.7\% (BD+WDDG8.7)

\begin{tabular}{|c|c|c|c|c|c|}
\hline \multirow[t]{2}{*}{ Subject } & \multicolumn{3}{|c|}{ Experimental diets } & \multirow[t]{2}{*}{ SEM } & \multirow[t]{2}{*}{ P-value } \\
\hline & BD & BD+WDDG5 & BD+WDDG8.7 & & \\
\hline \multicolumn{6}{|l|}{ Activity (min/d) } \\
\hline Eating & 317.22 & 330 & 308.33 & 10.81 & 0.18 \\
\hline Ruminating & 543.33 & 537.22 & 520 & 15.53 & 0.33 \\
\hline $\begin{array}{l}\text { Total chewing activity } \\
\text { Activity (min/kg DM) }\end{array}$ & 860.56 & 867.22 & 828.33 & 15.39 & 0.06 \\
\hline Eating & 14.2 & 14.52 & 13.84 & 0.48 & 0.41 \\
\hline Ruminating & 24.34 & 23.84 & 23.46 & 0.73 & 0.5 \\
\hline $\begin{array}{l}\text { Total chewing activity } \\
\text { Activity (min/kg NDF) }\end{array}$ & 38.55 & 38.42 & 37.24 & 0.83 & 0.26 \\
\hline Eating & 43.7 & 43.67 & 40.9 & 1.53 & 0.16 \\
\hline Ruminating & 74.89 & 71.38 & 69.33 & 2.2 & 0.08 \\
\hline Total chewing activity & $118.6^{\mathrm{a}}$ & $115.05^{a}$ & $110.24^{\mathrm{b}}$ & 2.38 & 0.01 \\
\hline
\end{tabular}

\section{CONCLUSION}

Results from this study indicate that WDDG may be incorporated into dairy cattle diets up to $8.7 \%$ without adversely affecting feed intake and milk production. In addition, yields and composition of all major milk components were similar for all the experimental diets. Similarity of milk fat percentage between present treatments implies that NDF of WDDG can effectively prevent milk fat depression. Therefore, it can be concluded, based on the results of this study, that inclusion of WDDG at up to $8.7 \%$, as a partial replacement of alfalfa hay, in lactating Holsteindairy cow diets does not appear to alter eating and ruminating (min $/ \mathrm{kg} \mathrm{DM}$ ) when the rations are formulated to meet the NDF requirements of the cows. Besides, replacing alfalfa hay with WDDG at up to $8.7 \%$ of dietary DM is a viable alternative for producers when forage is limiting. Wheat distillers' dried grains contain high level of undegradable protein and this may lead to a lower ruminal ammonia concentration, hence the low blood urea-N level in the animals fed BD+WDDG5 was expected.

\section{ACKNOWLEDGEMENT}

The authors would like to thank the financial support from Mr. M. Ghaemi (Wheat dried distillers' grain producer Co. manager) and Ferdowsi University of Mashhad. 


\section{COMPETING INTERESTS}

Authors have declared that no competing interests exist.

\section{REFERENCES}

Allen, D.M., Grant, R.J. (2000). Interactions between forage and wet corn gluten feed as sources of fiber in diets for lactating dairy cows. J. Dairy Sci., 83, 322-331.

Allen, M.S. (1997). Relationship between fermentation acid production in the rumen and the requirement for physically effective fiber. J. Dairy Sci., 80, 1447-1462.

Allen, M.S. (2000). Effects of diet on short-term regulation of feed intake by lactating dairy cattle. J. Dairy Sci., 83, 1598-1624.

Anderson, J.L., Schingoethe, D.J., Kalscheur, K.F., Hippen, A.R. (2006). Evaluation of dried and wet distiller's grains included at two concentrations in the diets of lactating dairy cows. J. Dairy Sci., 89, 3133-3142.

Armentano, L., Pereira, M. (1997). Measuring the effectiveness of fiber by animal response trials. J. Dairy Sci., 80, 1416-1425.

Association of Official Analytical Chemists (AOAC). (1990). Official methods of analysis, vol. I., 15th ed. AOAC, Arlington, VA, USA.

Batajoo, K.K., Shaver, R.D. (1998). In situ dry matter, crude protein, and starch degradabilities of selected grains and by-product feeds. Anim. Feed Sci. Technol., 71, 165-167.

Broddugari, K., Grant, R.J., Stock, R., Lewis, M. (2001). Maximal replacement of forage and concentrate with a new wet corn milling product for lactating dairy cows. J. Dairy Sci., 84, 873-884.

Clark, P.W., Armentano, L.E. (1993). Effectiveness of neutral detergent fiber in whole cottonseed and dried distillers grains compared to alfalfa haylage. J. Dairy Sci., 76, $2644-2650$.

Creswell, A.W. (1985). Separation of feed ingredients by flotation. Feed Age, 8, 33-44.

Cunningham, K.D., Cecava, M.J., Johnson, T.R. (1993). Nutrient digestion, nitrogen, and amino acid flows in lactating cows fed soybean hulls in place of forage or concentrate. J. Dairy Sci., 76, 3523-3535.

Dann, H.M., Varga, G.A., Putnam, D.E. (1999). Improving energy supply to late gestation and early postpartum dairy cows. J. Dairy Sci., 82, 1765-1778.

Firkins, J.L., Harvatine, D.I., Sylvester, J.T., Eastridge, M.L. (2002). Lactation performance by dairy cows fed wet brewers grains or whole cottonseed to replace forage 1,2 . J. Dairy Sci., 85, 2662-2668.

Grant, R.J., Mertens, D.R. (1992). Influence of buffer pH and raw corn starch addition on in vitro fiber digestion kinetics. J. Dairy Sci., 75, 2762-2768.

Hatch, R.H. (1993). Distillers' feed, grains are good source of feed, protein. Feedstuff, 65, 14.

Kalscheur, K. (2003). Feeding distillers' grain to dairy cattle: Impact on milk fat, protein and yield. Distillers Grains Quarterly, Second Quarter.

Kaske, M., Engelhardt, W.V. (1990). The effect of size and density on mean retention time of particles in the gastrointestinal tract of sheep. Br. J. Nut., 63, 457-465.

Mertens, D.R. (1997). Creating a system for meeting the fiber requirements of dairy cows. J. Dairy Sci., 80, 1463-1481. 
Mojtahedi, M., DaneshMesgaran, M. (2011). Effect of the inclusion of dried molassed sugar beet pulp in a low-forage diet on the digestive process and blood biochemical parameters of Holstein steers. J. Lives Sci., 141, 95-103.

Mustafa, A.F., McKinnon, J.J., Ingledew, M.W., Christensen, D.A. (2000). The nutritive value for ruminants of thin stillage and distillers' grains derived from wheat, rye, triticale and barley. J. Sci. Food Agri., 80, 607-613.

National Research Council.(2001). Nutrient Requirements of Dairy Cattle, 7th rev. ed. Natl. Acad. Sci., Washington, DC, USA.

Penner, G.B., Yu, P., Christensen, D.A. (2009). Effect of replacing forage or concentrate with wet or dry distillers' grains on the productivity and chewing activity of dairy cattle. Anim. Feed Sci. Technol., 153, 1-10.

Pereira, M.N., Armentano, L.E. (2000). Partial replacement of forage with nonforage fiber sources in lactating cow diets, II. Digestion and rumen function. J. Dairy Sci., 83, 2876-2887.

Pereira, M.N., Garrett, E.F., Oetzel, G.R., Armentano, L.E. (1999). Partial replacement of forage with nonforage fiber sources in lactating cow diets, I. Performance and health. J. Dairy Sci., 82, 2716-2730.

Rezaii, F., DaneshMesgaran, M., HeraviMoussavi, A., Nassiry, M.R. (2009). Effect of nonfiber carbohydrates on in vitro first order kinetic disappearance of neutral detergent fiber and neutral detergent insoluble nitrogen of wheat bran. Res. J. Boil. Sci., 4(5), 573-577.

Rezaii, F., DaneshMesgaran, M., HeraviMoussavi, A. (2010). Effect of non-fiber carbohydrates on in vitro first order kinetics disappearance of cellulose. Iranian J. of Vet. Res., 11, 139-144.

Rezaii, F., DaneshMesgaran, M., HeraviMoussavi, A. (2011). Effect of non-fiber carbohydrates on in vitro first order ruminal disappearance kinetics of dry matter an NDF of various feeds. Iranian J. of Vet. Res., 12, 222-229.

Swain, S.M, Armentano, L.E. (1994). Quantitative evaluation of fiber from nonforage sources used to replace alfalfa silage. J. Dairy Sci., 77, 2318-2331.

Van Soest, P.J., Robertson, J.B., Lewis, B.A. (1991). Methods for dietary fiber, neutral detergent fiber and nonstarch polysaccharides in relation to animal nutrition. J. Dairy Sci., 74, 3583-3597.

Weidner, S.J., Grant, R.J. (1994). Altered ruminal mat consistency by high percentages of soybean hulls fed to lactating dairy cows. J. Dairy Sci., 77, 522-532.

Younker, R.S., Winland, S.D., Firkins, J.L., Hull, B.L. (1998). Effects of replacing forage fiber or nonfiber carbohydrates with dried brewers' grains. J. Dairy Sci., 81, 2645-2656.

Zebeli, Q., Tafaj, M., Steingass, H., Metzler, B., Drochner, W. (2006). Effects of physically effective fiber on digestive processes and milk fat content in early lactating dairy cows fed total mixed rations. J. Dairy Sci., 89, 651-668.

(C) 2012 Gohari et al.; This is an Open Access article distributed under the terms of the Creative Commons Attribution License (http://creativecommons.org/licenses/by/3.0), which permits unrestricted use, distribution, and reproduction in any medium, provided the original work is properly cited. 